Canadian University Music Review

Revue de musique des universités canadiennes

\title{
Naomi Cumming. 2000. The Sonic Self: Musical Subjectivity and Signification. Bloomington: Indiana University Press. 370 pp. ISBN 0-253-33754-2 (hardcover)
}

\section{William Echard}

Volume 24, numéro 1, 2003

URI : https://id.erudit.org/iderudit/1014675ar

DOI : https://doi.org/10.7202/1014675ar

Aller au sommaire du numéro

Éditeur(s)

Canadian University Music Society / Société de musique des universités canadiennes

ISSN

0710-0353 (imprimé)

2291-2436 (numérique)

Découvrir la revue

Citer ce compte rendu

Echard, W. (2003). Compte rendu de [Naomi Cumming. 2000. The Sonic Self: Musical Subjectivity and Signification. Bloomington: Indiana University Press. 370 pp. ISBN 0-253-33754-2 (hardcover)]. Canadian University Music Review / Revue de musique des universités canadiennes, 24(1), 114-118. https://doi.org/10.7202/1014675ar

All Rights Reserved (C Canadian University Music Society / Société de musique des universités canadiennes, 2005
Ce document est protégé par la loi sur le droit d'auteur. L'utilisation des services d'Érudit (y compris la reproduction) est assujettie à sa politique d'utilisation que vous pouvez consulter en ligne.

https://apropos.erudit.org/fr/usagers/politique-dutilisation/ 
Laforte, Conrad. 1981. Survivances médiévales dans la chanson folklorique : Poétique de la chanson en laisse. Québec : Presses de l'Université Laval. . 1993. Poétiques de la chanson traditionnelle française: Classification de la chanson folklorique française. $2^{\mathrm{e}}$ éd. Québec : Presses de l'Université Laval.

—__ 1997. Chansons de facture médiévale retrouvées dans la tradition orale : Répertoire recueilli de 1852 à nos jours. Québec : Nuit blanche éditeur.

Le Blanc, Andrée. 1979. « La bonne chanson ou l'idéologie éducative au Canada français de 1938 à 1955 ». Mémoire de maîtrise, Université de Montréal.

Leclerc, Félix. 1988. Cent chansons. Présentation d'André Gaulin; entretien avec Jean Dufour; étude de Marie-José Chauvin. [Montréal] : Bibliothèque Québécoise.

Le Pennec, Jean-Claude. 1967. L'univers poétique de Félix Leclerc. Montréal : Fides.

Maloney, Timothy S., et al. 2001. Encyclopédie de la musique au Canada. http://www.collectionscanada.ca/emc/index-f.html (consulté le 15 mars 2005).

Remon, Lina. 1993. Madame Bolduc : Paroles et musiques. Collab. JeanPierre Joyal. Montréal : Guérin.

Roy, Bruno. 1991. Pouvoir chanter. Montréal : VLB.

Seline, Janice, et al. 1980. L'illustration de la chanson folklorique au Québec des origines à La bonne chanson. Montréal : Musée des beaux-arts de Montréal.

Thérien, Robert. 1998. Le gramophone virtuel : Enregistrements historiques canadiens. http://www.collectionscanada.ca/gramophone/index-f.html (consulté le 15 mars 2005).

2003. L'histoire de l'enregistrement sonore au Québec et dans le monde : 1878-1950. Québec : Presses de l'Université Laval.

Tremblay-Matte, Cécile. 1990. La chanson écrite au féminin : De Madeleine de Verchères à Mitsou, 1730-1990. Collection « Trois Guinées ». Laval : Trois.

Zimmermann, Éric. 1999. Félix Leclerc : La raison du futur. Montréal : Éditions Saint-Martin.

Luc Bellemare

Naomi Cumming. 2000. The Sonic Self: Musical Subjectivity and Signification. Bloomington: Indiana University Press. 370 pp. ISBN 0-253-33754-2 (hardcover).

It is rare to find a book which is both sweepingly ambitious and disarmingly elegant. The Sonic Self is such a book. The work could justifiably be placed in several different lineages: it is a study of musical narrative and persona; it is a book of reflective, personal new musicology; it engages central questions of musical aesthetics; it expands the metatheory of music analysis; and it has 
contributions to make in the study of pedagogy and violin performance practice. This richness derives from Cumming's choice of topic. The Sonic Self asks how musical sound and the rituals of pedagogy and performance form musical subjects on several different levels. Cumming considers the self-constitution of performers, the construction of performer as persona in reception and criticism, and the nature of subjectivity on the part of musical sound itself. The primary theoretical lens through which this program is developed is Peircian musical semiotics, with a special focus on its philosophical aspects. Cumming's own broad background prepared her especially well for the production of such an interdisciplinary study. From an early age she trained as a classical violinist, and remained a dedicated performer throughout her life. She also pursued advanced training in music theory, pedagogy, and western philosophy. In 1998 she was granted the International Society for Music Theory Outstanding Publication award for her article on Bach's "Erbarme Dich." It is to be expected, then, that her work would weave together issues and methods from a range of sources. The pleasant surprise is her deft syntheses of the material. Also worth noting, the book always feels strongly motivated without ever lapsing into dogmatism. Considering the highly technical and sometimes partisan nature of the literature on musical meaning and subjectivity, this is a welcome achievement.

In the years preceding and including the writing of this book, Cumming had dedicated herself to the formal study of western philosophy, and it shows in the style of her writing. There is no barrage of technical arguments, but instead, a smaller number of examples and comments which, while remaining approachable almost to the point of transparency, manage to raise an extraordinary number of questions. Similarly, Cumming states her own positions in a manner which should be entirely clear for readers not familiar with the technical literature, but which for specialist readers (or at least for this specialist reader) is often impressive in range and concision. Especially welcome is the Appendix, entitled "Theorizing Generals," in which Cumming broaches the already familiar debate about essentialism versus constructivism, but does so from a philosopher's perspective. This short passage alone could provide an important opening to new possibilities in that still-central debate.

The book opens with reminiscence. Cumming tells us what it was like for her, as a child and young adult, learning to play the violin. These passages are engaging and even moving, delineating both the human stakes of the study and also her technical and theoretical concerns. When she moves on to the core of her argument, echoes of this personal opening continue to linger, although they are nuanced and extended by her theoretical view of subjectivity. Cumming emphasizes the manner in which subjectivity and expressivity are constructs read into sonic and other texts. She emphasizes the fact that these qualities may in some cases be entirely virtual. There are two senses of virtuality here: (1) the attribution of an emotional or intellectual state to a performer who does not actually inhabit such a state (even though some listeners may hear it "expressed" in the music); (2) the many cases in which the music itself seems to 
exhibit subjective states (i.e., in which musical sound itself seems to function as a kind of subject). Cumming's semiotic orientation towards these phenomena is premised partly on the idea that signs and therefore meanings are in large measure public phenomena, not inner ones. Such a position may, in extreme forms, diminish our attention to the unique personalities and experiences of individuals. However, even while Cumming strongly argues for the public nature of meaning, she keeps in view the importance of subjectivity to social actors. She does not diminish the feeling of inwardness, nor undermine the uniqueness of each subject, even as she places these in the setting of a trans-subjective semiosis. In addition, Cumming's work is unique in the degree to which she theorizes this admittedly familiar territory with minute attention to the creation and interpretation of musical signs, from performative nuances such as exact vibrato to the most general structural features as revealed in Schenker-style formal graphs.

One philosophical concept used to good effect by Cumming is synthesis. The term has diverse meanings for philosophers as diverse as Kant, Heidegger, and Deleuze, and is also linked to a central concern of Peirce's semiotics: the way in which signifying practices aim to reduce complex webs of perception and action to some kind of unity. In Cumming's work, synthesis is used as a concept to explain the way in which various sign instances can be made to cohere into subjectivities. This applies both to the human subject as social actor, and to the creation of virtual subjects in musical sound. Both of these phenomena have been explored by earlier authors, but Cumming's work is unique in the degree to which she brings them together. In her writing, it is possible to clearly experience a liminal zone in which subjectivity is something developed and manifested both in the human actor and in the music itself. This melding of human and musical subjectivity is not the result of lax generalization, however, but rather presented through careful and well-grounded arguments, both philosophical and musicological.

In terms of its place within the semiotic literature, The Sonic Self does not introduce radically new directions, but does offer the best available discussion of some important pre-existing approaches. Top on the list is the rigorous and exceptionally clear presentation of Charles Peirce's semiotic, considered as a part of his broader philosophical program. For any non-Peircian curious about why and how Peirce may be applied to musical analysis, this is the place to start. Similarly, Cumming offers forceful (although not always irrefutable) arguments for the distinctiveness and necessity of a semiotic perspective, and takes special care to distinguish this perspective from that of cognitive science, with which it may sometimes be confused. Finally, for readers interested in theories of gesture and embodiment, Cumming presents important and in some respects sweeping extensions to this approach.

Clearly, this is a book with wide-ranging strengths, but that is not to say that it is perfect. As is often the case, one of the book's most effective features also becomes something of a problem. On the one hand, Cumming argues for the self as public construct, while on the other hand she empathically conveys the 
texture and stakes of individual experience. As already noted, this allows impressive strides in theorizing the construction of subjectivity. It also allows her to bring together, under the same theoretical rubric, "real" human subjects and "virtual" musical ones. However, it is never made clear whether Cumming actually endorses the extreme liminality which this viewpoint introduces into the subject. Her writing vividly conveys the solidity and agency of subjects, but her theoretical perspective tends to de-territorialize them, situating them neither in the individual nor in the collective. Again, this could easily be turned into a theoretical strength, if it were linked to a more explicit consideration of the relationship between singular occurrences and general contexts. And such a criticism would not even have the chance to arise were it not for Cumming's high level of theoretical sophistication. But it is striking that her book raises the issue so clearly without offering a clear statement as to what sort of resolution she would ultimately prefer. In places Cumming does introduce topics that could form part of such a position, for example in her discussion of emergence as an ontological problem, but these could have been more effectively focused on what to my mind is the central open issue: the nature and actual location of subjectivity.

Also, there are important topics which the book broaches but does not develop in sufficient depth. For example, in the second half of the work Cumming raises the importance of cultural context, but her argument does not advance much past already established critiques of absolutism. In other words, Cumming wisely raises the question of meaning's context-sensitivity, but discusses it without any largescale use of social theory, and as a result sometimes misses important distinctions. For example, she makes the important decision to discuss the claims of music theory with respect to lawfulness in general, but to my mind the discussion fails to be convincing because it does not adequately distinguish between the different kinds of imperative embodied in natural laws and in social norms. The raw materials for this distinction are in fact raised throughout the book, but not mobilized in that direction at the crucial moment. In general, there are several points such as this in which the existing literature on cultural theory of music has more sophisticated models to offer, and it would have advanced Cumming's argument if she had incorporated more of these sources. A related criticism could be that there is nothing here resembling a comprehensive literature review. The literature related to Cumming's concerns is massive, so in a sense this is strength. And it is impressive that she manages, without such a review, to cover just about all the relevant debates and to arrive at a defensible position on most of them. On the other hand there is a tradeoff between the transparency of the presentation and the large number of works and traditions that go unmentioned. The book represents a superlative. job of cherry picking, but may in places be frustrating for readers devoted to one of these other viewpoints. For example, both Deleuze and Bakhtin loom large over some of the debates engaged by Cumming, but the first is not mentioned at all, and the second appears only briefly and is not discussed at length. Similarly, the considerable literature on subjectivity developed in popular music studies does not receive any significant notice in the book. 
Despite these shortcomings, my ultimate assessment is closer to the highly positive tone with which I opened this review. Cumming has achieved a unique and impressive synthesis of music theory, semiotics, aesthetics, and philosophy. She has crafted a theoretical perspective which is complex and subtle while remaining approachable, and has deftly applied it to one of the most important questions in current musicological debate: how are subjectivities constructed through music, both as text and as practice? I would strongly encourage anyone with an interest in such questions to read this book as soon as possible.

\section{REFERENCE}

Cumming, Naomi. 1997. "The Subjectivities of 'Erbarme Dich'." Music Analysis 16, no. 1: 5-44.

William Echard

Elaine Barkin and Lydia Hamessley, eds. 1999. Audible Traces: Gender, Identity, and Music. Zurich: Carciofoli Verlagshaus. Verbal score, index, CD, 292 pp. ISBN 3-905323-00-1 (hardcover).

Tullia Magrini, ed. 2003. Music and Gender: Perspectives from the Mediterranean. Chicago: University of Chicago Press, 371 pp. ISBN 0226501655 (hardcover).

In the last five years, several new anthologies on gender and music have appeared, each extending the issues and approaches of this important sub-field of music scholarship. This review explores two collections that are innovative in dramatically contrasting ways. While, at the end of my close reading of the two books, I think the Magrini will have a greater impact, the Barkin / Hamessley volume will also inform my future reading lists.

Audible Traces: Gender, Identity, and Music by Barkin and Hamessley is arguably the book that risks the most in its unmodified celebration of "experience" and its presentation of multiple modes of representation, including composers' personal accounts, poetry, diary entries, and a "score" with audio on the accompanying $\mathrm{CD}$. There has been a tendency to move away from such forms of experimentation in the past few years and hence this volume may represent an experimental moment the significance of which will echo differently for different reader/listeners. I really enjoyed the diverse writing styles.

The insistence on individual diversity, indeed in some articles the downplaying of groupness, including, in some cases, any acknowledgement of a priori gender consciousness, is a further characteristic, one that contrasts with the Magrini anthology that is reviewed below. Is this a new form of denial for the social groundedness of artistic practices, or is it an antidote to some overly deterministic accounts of gender, class, and race? This particular insistence on individuality is perhaps related to the fact that the book is a collaboration between a musicologist and a composer; indeed, composers' voices are quite 